$\underline{\text { Interview }}$

\title{
Interview with Marina Gržinić
}

\author{
Sally R Munt ${ }^{1 *}$
}

Published: September 8, 2020

\section{INTRODUCTION}

Marina Gržinić (1958- ) is a philosopher, theoretician, and artist based in Ljubljana, Slovenia. She is a prominent contemporary theoretical and critical figure in Slovenia. Since 1993, she has been employed at the Institute of Philosophy at the Scientific and Research Center of the Slovenian Academy of Science and Arts (ZRC SAZU). Since 2003, she has also served as Full Professor at the Academy of Fine Arts in Vienna, Austria. Gržinić does innovative work in practice research, she is a collaborative video artist, and since 1982 has worked together with Aina Šmid, an art historian and artist also from Ljubljana.

In 1980s Ljubljana, Marina Gržinić was engaged in the constitution of what is generally known as the Ljubljana alternative or subcultural movement that was developing new artistic practices (like video and performance), politically engaged movements such as the gay and lesbian scene, and many other processes that were constitutive for the discussion of the position of art and culture in Slovenia. At that time, these activists demanded and struggled for a political, emancipated life that would bypass middle class bourgeoisie perceptions of Slovenian society and reality. Gržinić's theoretical work is informed by contemporary philosophy and aesthetics after modernism. Her work is directed towards a theory of ideology, theory of technology, biopolitics/necropolitics, video technology and transfeminism in connection with the political aims of decoloniality.

Gržinić's work cannot be easily circumscribed in this or that school or discipline, though in recent years, she's brought to Slovenia an increased awareness of global critical philosophy, which is focused on considering the local, against racism, coloniality, and questioning the necropolitics of global capitalism.

Gržinić has been involved in many video film presentations and curatorial projects. A selection of her books includes: New Feminism: Worlds of Feminism, Queer and Networking Conditions (co-edited with Rosa Reitsamer, 2008), Necropolitics, Racialization, and Global Capitalism: Historicization of Biopolitics and Forensics of Politics, Art, and Life (with Šefik Tatlić, 2014), and Border Thinking: Disassembling Histories of Racialized Violence (editor, 2018).

Could you tell us something about your intellectual journey - what do you see as your primary academic identity or concerns now?

Let me explain the context of cyber-feminism in Europe. In Documenta X, Kassel, Germany, 1997 was held the First Cyberfeminist International, ${ }^{2}$ organised by the Old Boys Network. In 1999 in Maribor, Slovenia, as part of the Festival of Computer Arts, I edited in collaboration with Adele Eisenstein the book The Spectralization of Technology: From Elsewhere to Cyberfeminism and Back. Institutional Modes of the Cyberworld, in which vital cyber feminists such as Cornelia Sollfrank, Claudia Reiche, Eva Ursprung, Kathy Rae Huffman, Margarete Jahrmann took part in contributing to and consolidating that historical moment in feminist critical thinking. The Spectralization of Technology outlined a commitment to feminism, technology, and an entanglement of technology and gender, in a revolt against digital patriarchy and capitalism - discrimination not only in the real but as well in the virtual space. From that time

${ }^{1}$ Documenta $X$ was the tenth edition of quinquennial contemporary art exhibition, held between 21 June and 28 September 1997, in Kassel, Germany. It was the first time a woman, French curator Catherine David, was appointed as its artistic director (see Documenta, n.d.).

2 The First Cyberfeminist International was the first big meeting of cyberfeminists. Old Boys Network (OBN), the first international cyberfeminist organisation invited 37 women from 12 countries to discuss the concept of feminism and as a substitute for finding its definition formulated '100 Anti-Theses' (see https://www.obn.org). 
onwards in western capitalism, technology and gender has changed radically; the dominant regime of whiteness made many things exclusive and only for white women in the Occident; such notions and conditions are imbued with persistently violent relations of power, management of subjectivity and so on. Both my artistic endeavours and my theoretical work are preoccupied with what it means to be a human being in this time of a hyperdigitalisation, quantum computers, transhumanist discourses, and I seek to analyse themes of life and death.

In relation to this intellectual history I have been preoccupied by the representation and treatment of refugees in Europe. Currently, the situation of asylum seekers and refugees and the status of their lives and bodies in the detention camps in Europe, at the borders of the European Union, or as corpses recovered from the Mediterranean Sea cannot be described solely as unwanted deaths, fate or destiny. These situations of massive suffering, death, and misery are also connected to specific historical conditions that both differ from and are in continuity with what we have here and now. In other words, what we are seeing is an evolving process of persistent dehumanisation at the centre of the more and more post-human, prosthetic, digitalised global capitalism.

The fundamental relationship in these horrific practices of immigration control is the relationship between death and life. This is not only connected with immanent philosophical questions such as 'What is life?' and 'What is death?' but is also, increasingly, concerned with the elaborate ways of governmentality over life and death, with strategies and techniques through which life and death are managed, run, controlled by the state, by governments and by their various institutions. We are seeing a paradoxical situation that in contemporary capitalist societies are promoting the promise and rhetoric of making life better - a process that is known in critical theory by the word 'biopolitics' - but this is increasingly not really the case today. Biopolitics is a term coined in the mid-1970s by noted French philosopher Michel Foucault (2010) (who died in 1980); he posited a link between LIFE (Latin: bio) and politics. Since 2001, we have been witnessing an antithesis: neoliberal global capitalism is producing value (profit, control) through management not of life but, instead, of death. So global capitalism is a capitalism of DEATH. It is a regime of power, economics, and aesthetics that posits a link between DEATH and politics that the South African theoretician Achille Mbembe (2003) named necropolitics. It was 40 years after Foucault that Mbembe argued that global capitalism is necropolitical, as it decides today only and solely 'who may live and who must die' (2003: 11). This demands from a feminist's perspective a new politicisation away from biology toward a new political reconfiguration of women as a political movement.

My thinking about cyberfeminism over the past few decades has crystallised recently. Moreover, what we experienced in 2020 across the world in relation to a very real life/death threat to the body, the Corona virus, is a sense of anxiety, not fear. Massimo Recalcati (2019) stated that fear is an emotional response that is connected with an object, with a visible coming danger, like a weather disaster or similar. With the epidemic of Covid-19, the threat is not localisable. Anxiety is connected precisely with not having an object of danger, but just an internalised image. This passage from fear to anxiety changes our ways of how to react, what to think, what to do. Elisabeth Bakambamba Tambwe (personal communication, 1 May 2020) commented very precisely: 'all in the 21st century was presented that is about technology, and now we see clearly in the time of Covid-19 that all depends on us, on humans.'

Voila, in the pandemic of 2020, the myth of the posthuman is disintegrating at our thresholds.

However, I am privileged as I have still a wage, but we need to urgently give attention to the hyper-precarious - what is happening to them?

\section{What intellectual traditions from Eastern Europe have you found specifically useful and influential?}

Since the 1970s, it became clear for many of us that sex and gender are not some natural states, but are formed always in connection with a particular social relation. Contrary to the stiff, conceptual binary opposition of two complementary and at the same time exclusive categories of men and women, a binary that brings back naturalisation of the binary on which resides the regime of gender, woman (femininity) and man (masculinity) has been argued to and for 50 years. In 2004 I engaged with what Antonella Corsani (2007) defines as 'Beyond the myth of woman: The becoming-transfeminist of (post-)Marxism.' The later question of transfeminism opened up possibilities for transformation, even more so the questions of homosexual and queer positions in connection with the transmigrant, as argued by Tjaša Kancler (2013: 14-15), in a position coming from former Eastern Europe. This should be clarified, saying that today due to technological prosthesis, pharmaceutical products, and new digital technologies it is almost impossible to determine where the boundary passes between natural bodies and those fabricated by the interventions of artificial technologies such as cyber implants, electronic prostheses, hormones, tablets, organ transplantation and so on.

In 2005 Rosa Reitsamer, a lesbian theoretician from Vienna, exposed centrally a critique of the regime of whiteness. In her talk 'In the mix: Race, whiteness and gender in popular culture' (presented at the 2005 City of Women festival in Ljubljana), she exposed performativity and racialisation as processes of discrimination that connect race with class and gender and which have the modality of structural and social racism. This was connected to what US feminist theorist Kimberlé Crenshaw had described as intersectionality in 1989. We cannot isolate 
ourselves in thinking. Simply to state in the 1970s parallel to the feminist movement in the USA it was strong feminist groups in Zagreb (Croatia) and Serbia (Belgrade). These groups of academic powerful women, declared feminists, followed what was going on in the 1970s in the outside world. In the 1980s and 1990s the powerful gay and lesbian scene in Ljubljana Slovenia did the same.

The emergence of Slovenian punk in 1977, along with the first coming out of the gay scene in 1984, with a festival entitled Magnus: 'Homosexuality and Culture's represented something entirely new and different behind the Iron Curtain in Europe. These two movements (punk and homosexuality) transformed us into urban entities; they opened up the possibility of conceptualising anti-authoritativeness, different sexualities, the anti-hegemonic battle against patriarchy and chauvinism, the normalisation of everyday life, and the revolt against depoliticisation.

Contemporary theory and political discourse likewise had a huge impact on our view of the world. Heavily implicated into the whole thing were also the contemporary theories of French structuralism, post-structuralism, Lacanian psychoanalysis, and British lesbian and gay theory and practice, as well as postcolonial studies and the mass media.

Although the first LGBTQ event in Slovenia dates back deep into the times of socialism, in 1984 in Ljubljana with 'Magnus - Homosexuality and Culture,' the first Pride parade in Slovenia was not organised until 2001, and this was only the immediate result of a direct provocation: an incident in a Ljubljana cafe where a gay couple was asked to leave for being homosexual.

All of this historical radicalism has been presented by activists and writers such as Tatjana Greif, Suzana Tratnik, Nataša Sukič, Nataša Velikonja, Urška Sterle, Kristina Hočevar, Nina Hudej, Petra Hrovatin, Simona Jerala, Barbara Rajgelj, and more—all strong voices within the lesbian movement in Slovenia; and Mojca Dobnikar and Aigul Hakimova, representing feminist, activist and migrant positions from Slovenia; and Lepa Mlađenović, Zoe Gudović, and others, from Belgrade; and Sanja Juras, Danijela Almesberger, Nela Pamuković, and others, from Zagreb. These are just some of the activists that in the last decades have politicised the space of former Yugoslavia and Eastern Europe, through gender, feminism, lesbianism. Their work is connected also with the first generations of feminists such as Žarana Papić, Daša Duhaček, and Biljana Kašić. Another hundred names should be mentioned here, I risk partiality, nevertheless I want to emphasise that our work relates to each other, to a community of political activism which depended upon lesbian, gay, trans* positions. In the last decade strong trans* voices and gay positions emerged from former Yugoslavia as Tjaš* Kancler and Piro Rexhepi became essential for my work. This is inside the space of former Yugoslavia. But we do not live inside a 'geopolitical territory,' we live in the world, therefore the space of former Yugoslavia would not exist in political, emancipatory ways without the decolonial, lesbian, transfeminists, and Afropessimists thoughts, visions, and horizons.

In reflecting backwards, what is important is to see two moments at work. On the one side, it is a demand for each of us to perform an analysis of power and yet on the other also to perform that regime of control. I see more recently that this white anti-racism is changing into a disturbing direction of self-promotion, or, as described by Derek Hook (2011), a paradoxical instrument of 'white self-love.' This has also been heavily criticised by the Black and migrant positions. Kancler argued that today:

... the biological principle and ontological difference are called into question through positions that deconstruct the concept of 'woman' and 'man' in favor of the political thought of differential differences, undisciplined sexual, ethnic and racial multiplicity, which according to Antonella Corsani goes beyond the binary system as the epistemological and political core and causes new shifts of categories, discourses, political forms and borders. (2013: 17-18)

Alongside this critique of binarism, it is necessary to emphasise the transformation of feminism into new-, postand trans-feminism positions that are working with and through relations of the agency together with migrants' positions, Black diaspora, and Women of colour positions. One of the crucial points in these processes was the emergent attack on the regime of whiteness and capitalism. The outcome was the deconstruction of feminism with and by postcolonialism, and after 2000 with the decolonial turn of postcolonialism. ${ }^{4}$ What is clear is, as argued by

\footnotetext{
3 The first Magnus festival, organised by ŠKUC-Forum and held in Ljubljana (at several venues: Skuc Gallery, KinoSkucKrižanke, Faculty of Philosophy, Disko FV), took place between April 24-29, 1984, and presented European and American gay films, exhibitions, lectures and discussions about gay culture and organisations. The festival is considered as the beginning of Gay and Lesbian Film Festival of Ljubljana, the oldest of LGBT film festivals in Europe. Slovenia's first gay organisation, Cultural Organisation for Socialisation of Homosexuality, was established in December the same year and was named Magnus after the festival (see http://www.magnus.si/en/).

${ }^{4}$ The decolonial turn of postcolonialism dates back to the 1998 conference/dialogue at Duke University USA by the South Asian Subaltern Studies Group and the Latin American Subaltern Studies Group. This conference was the last time that the Latin American Subaltern Studies Group met. As Ramón Grosfoguel argues, 'among the many reasons for the split of the Latin American Subaltern Studies Group, one of them was between those who read subalternity as a postmodern critique (which represents a Eurocentric critique of eurocentrism) and those who read subalternity as a decolonial critique (which represents a critique of eurocentrism from subalternised and silenced knowledges)' (2007: 211).
} 
Kancler (2013: 17), that the last decade has witnessed a process of de-identification with the category of 'woman,' that means it put under question the category of 'woman' as the subject of the historical feminist struggle. This also asks for the deconstruction of masculinity and male gender (associated with beliefs like the spin on De Beauvoir's 'One is not born man but rather becomes one,' or 'Gays are not men').

What Kancler (2013: 17) exposes are processes that were triggered by the fact that lesbians, gays, transgender, intersex, transsexuals, women of colour, 'Chicanas' (Mexican American women) and others took a creative and strategic stance on the level of political statement to bring about the formation of identities that are not fixed but changed through the constant process of becoming. According to trans* feminist Paul (Beatriz) Preciado (2013), who has been active in European queer thought and curation, sex persists as the last remnant of nature; even after technology has completed its task of reconstructing the body. Preciado therefore indicates that in the sense of technological intervention (technologies of gender), this relation unties the contradiction of essentialism and constructivism. Thus, we can replace, as they point out, sex and gender with the word 'technogender'5 because the bodies can no longer be isolated from the social forces of sexual difference.

\section{Could you tell us some more about your engagements in the 1980s with alternative cultural and political movements in Ljubljana?}

In 2011 in the radio program 'Lezbomanija' [Lesbo mania], which was hosted by Nataša Sukič on Radio Študent, Ljubljana (see https:// radiostudent.si), to reflect different histories and conditions for a politics of class, race, and gender I stated that 'Before being feminists, we were lesbians.' In this way, I indicated the necessity for the persistent articulation of the political subject of the feminist movement, which in the 1980s in Slovenia expressed itself first as a lesbian political stance. I pointed toward a redefinition of the political subject and its history, which has become a strategic weapon in the concrete social space.

The coming out of gays in Slovenia, as I already pointed out, occurred in 1984 with a festival entitled 'Magnus: Homosexuality and Culture' that was held at the Student Culture Center (ŠKUC) ${ }^{6}$ in Ljubljana. In 1987 there followed the public coming out of lesbians. The gays and lesbians coming out into socialism initiated discussions for equal rights, and these discussions were not formerly present in the public debates. These debates were initiated only by the LGBT community that did (and is still doing) a lot of political and social work, vigorously and publicly exposing different modes of discrimination.

These were impressive years of civil rights festivity in Slovenia, in the late twentieth century, though the 2000s brought in another reality. On March 25, 2012, a public referendum was held in Slovenia on the proposed new family code. ${ }^{7}$ The family code bill, if accepted, would have expanded existing same-sex registered partnerships to have all the same rights of married couples, excepting adoption (excluding step-child adoption). It would have expanded provisions protecting the rights of children, such as outlawing corporal punishment and establishing a children's ombudsman. The code was rejected, with $54.55 \%$ of voters against the law. A conservative group 'Civil Initiative for the Family and the Rights of Children,' in sympathy with the Catholic Church and various right-wing socially conservative political parties in Slovenia opposed to same-sex unions gathered the required signatures to force a negative vote.

\section{What was happening in Slovenia with gender politics pre- and post-independence?}

Global capitalism constantly renews itself with strategies of re-westernisation, and of brutal biopolitics (managing life) that transforms relentlessly into necropolitics (managing death), with continuously reinvigorating precarisation and outsourcing of the more and more class and race antagonised and socially excluded positions within the job market.

Since 1991, Slovenia, alongside gaining its independence, has erased/nullified (as an act of its necropolitical sovereignty) around 30,000 people to whom it owed a legal status. The 'Erased' (in Slovenian izbrisani) were mainly people from other former Yugoslav republics, who had been living in Slovenia. They are mostly of non-Slovene or mixed ethnicity, and they include a significant number of members of Romani communities. Some of those affected by the 'erasure' included former Yugoslav People's Army officers. They did not apply for or were refused Slovenian citizenship often because they participated in the war against Slovenia or were otherwise deemed disloyal

\footnotetext{
${ }^{5}$ With the concept of 'technogender' Preciado interprets the gender as constructed through technologies, hormones, surgery, prosthesis, etc. Preciado argues that in the twenty-first century, gender 'functions as an abstract mechanism for technical subjectivisations; it is spliced, cut, moved, cited, imitated, swallowed, injected, transplanted, digitized, copied, conceived of as design, bought, sold, modified, [...]. It transmutes' (Preciado, 2013: 129).

${ }^{6}$ ŠKUC beginnings are connected with Ljubljana's first radical student movement of 1968. It was formally established on January 31, 1972. ŠKUC was one of the key initiators, supporters and promoters of alternative culture in the late 1970s and in the 1980s. Today it is one of the leading non-governmental organisations promoting non-profit cultural and artistic activity in Slovenia (see https://www.skuc.org).

${ }^{7}$ For the Slovenia's current Family code see PISG (n.d.).
} 
to Slovenia. Some of the 'Erased' were born in Slovenia but, based on the republican citizenship and birthplace of their parents had remained citizens of other Yugoslav republics. Others had moved to Slovenia from other parts of Yugoslavia before the country's dissolution and remained thereafter 1991. This erasure of 30,000 people was not a preoccupation with the majority of Slovenians and less of the mass media. The Erased people are a clear measure of State racism in 1991.

Then, four years after the independence, in 1995, it was proposed by the Slovenian state agency and together with EU money to hold an international festival only for women, The City of Women [Mesto žensk], ${ }^{8}$ to act as a corrective for the perceived under-representation of female artists in public projects. The City of Women in many respects was a great initiative albeit of western prioritised gender equality, but it had its troubling darker side, as the festival made invisible other two processes of brutal discrimination: the 'Erased' people and the unequal status of gays and lesbians. While the 'Erased' people were produced as a 'new' European non-citizens without any human rights, the situation of homosexuals in Slovenia repeatedly presents the production of the second-grade citizens. I am elaborating racialisation as a process of capital's differentiation between citizens (first and second grade citizens), non-citizens (refuges, asylum seekers), and migrants; they are all violently, but differently discriminated against, as the labour market under global capitalism relentlessly imposes violent abuses based on racial, class and gender criteria on im/migrants in Europe.

It is still an open question of how to perceive the City of Women historically, as a negative-utopian or an affirmative-ironic version of women subjects' participation in the society at large at that time, and going forward. Back in 1995, this was criticised at the time as a capitalistic solution that was essentially anti-feminist. The City of Women did not present itself as explicitly feminist though, something akin to Wittgenstein's 'subject [that does] not belong to the world, [as] it is a border of the world,' as Marina Vishmidt (n.d.) indicated when reflecting on feminism and politics. The festival presented a kind of free-market inspired women's 'liberation', that soon made easier the implementation of turbo-driven neoliberal capitalism in the East of Europe. Nevertheless, it is possible to argue that the City of Women in Slovenia opened up important and timely topics for reflection in the context of global capitalism.

\section{How have issues like intersectionality been addressed in feminist politics in Slovenia?}

I would argue that the white western anti-racism politics that are performed by and within the regime of whiteness itself is becoming more grandiose and a caricature of anti-racism that all too often goes into a direction of self-promotion and 'charitable anti-racism,' an unreflective form of racism. Charitable anti-racism was very much present in the last years in Slovenia when several middle class female public figures collected money and cooked demonstratively in public (abundantly covered by the mass media) for migrant workers from former Yugoslav republics that were working temporarily in Slovenia but had lost their jobs. (Better to explicitly state that they were brutally fired, and kicked out of the company on the street without any payment.) This was because of a growth in company frauds and bankruptcy at the time, and the repressive state apparatuses and different state offices did not penalise the companies for their brutal infringement of workers and human rights, but simply started to deport the temporarily employed or unpaid workers to the other side of the Slovenian Schengen border. The performance of charitable anti-racism did not substantially change the rights of the workers, and I would argue was done in bad faith.

Slovenia as a European state is certainly not separate from the ravages of neoliberal anti-humanism. In all these processes, the human (as the outcome of a capital's regime of humanisation and as contemporary human capital subsumed in the unfinished project of western modernisation) stays mostly untouched. The Occident doesn't want to deal with it and therefore engages all imaginable post-human modes. In contrast, the present and historical modes of Occidental colonial de-humanisation remain mostly undiscussed. This relation opens up new perspectives and challenges on the whole process of becoming human or civilised in Europe. Araba Evelyn Johnston-Arthur describes the situation in Austria as twofold: on the one side, we have migrants who were invited into the country by the government in the 1960s to help the post-war reconstruction of the country. On the other hand, we have a new, expanding group of refugees, fugitives, asylum seekers, and deported persons who find themselves victims of ever-changing immigration laws established and reinforced on a daily basis by the EU and tailored, implemented and improved by the nation state (Johnston-Arthur and Kazeem, 2007).

This leads to a process of internal division and conflict that could be named in relation to Franz Fanon's 'Zone of Being and Zone of Non-Being' (1967). It makes a sharp contrast not only between the former Eastern Europe and 'former Western Europe,' but also in relation to the Black diaspora citizens, refugees and asylum seekers in Europe.

I am interested in this new Europe that (in the same way as global capitalism) can be described, by Angela Mitropoulos (2009: 5) as: the 'confluence of foreigners, slaves, women and children'. To her definition I add

${ }^{8}$ City of Women - Association for the Promotion of Women in Culture was founded in 1996 in Ljubljana, Slovenia (see http://www.cityofwomen.org/en).

(C) 2020 by Author/s 
migrants and all those who disrupt 'an authentication of power through origin-stories and their transmission, as fact and naturalised foundation' of Europe and the global world. I argue (with reference to Mitropoulos) that Europe today - in its most basic sense - is constituted by 'the problem of the legal form of value, of its imposition and perseverance,' and by 'origin and lineage' (Mitropoulos, 2009: 5).

Europe's migration/labour, capital, sexual reproduction, and race/ethnicity are nowhere more disputed and uneasy than at its frontiers between the former spectral East and 'former' Western Europe. This is a meeting point of 'natural' citizens and migrants, colonisers and descendants of the colonised, in the European Union and nonEU states. Europe is renewed today through a genealogy that excludes all those who are seen from its Western perspective as unimportant (that are further constructed ideologically as subhuman through a process of dehumanisation). This process stays insufficiently reflected upon, also in part due to the new rhetoric developed in contemporary philosophy and its theory of the posthuman.

Could you tell us a little about yourself as an artist? Your work with Aina Šmid spans 40 years, how fundamental has gender and feminism been in your own art production and how have these themes changed?

The form by which hierarchical relations are reproduced from country to country, and the way countries are positioned in relation to each other (who is inside the EU and who is outside) - such as sorting of bodies, which enables the free movement of products while forcing so many people to remain in total immobility (incarcerating them in refugee centres, halfway houses, and transit camps), is a (monstrous) image of the European reproductive model (chauvinistic, racist and deeply fascistic) for protecting neoliberal capitalist democracies. Consequently, to be a woman, and especially to be a Black woman or a woman from outside the EU, means to be treated as a voiceless victim without proper civil rights.

In the 1980s, we attempted to find out if we could apply our feminist and radical ideas about art and politics to a critical interrogation of socialism and its ideology. At the time, underground art, no less than alternative culture and politics, was under the constant surveillance of Yugoslavia's socialist state apparatus and its repressive institutional structures.

In the first half of the 1990s, the development of our video art was profoundly connected with the conflicts and wars in the Balkans. ${ }^{9}$ This period begins with the video Bilocation (1990, see Figure 1 ) and continues with The Sower (1991, see Figure 2), Three Sisters (1992, see Figure 3), Labyrinth (1993, see Figure 4), and Luna 10 (1994, see Figure 5). The links between the politics of the body, history, and the theory of video are clearly apparent in our first production Bilocation. The title itself refers to the notion of the body residing in two different places simultaneously. Indeed, this idea of being in two or more different places at the same time (war, history, revolution) or impossibly uniting two levels of meaning - of history and of the (political) body glimmering in the present, or vice versa - is a perfect description of a process basic to video and remained a core theme in our 1990s work.

I would argue that, because the video image (unlike film) has no depth, these electronic video pages are territories impregnated with blood. The video suture - the joining of the edges where two or more video images, or pages, collide - is not merely the intersection of juxtaposed empty scenes; on the contrary, this suture can be the bloodstain of excess. All of this led to a certain radical turn in film history. Jean-Luc Godard, defining French New Wave cinema (which was at its height in the period 1958-1964), said: 'It's not blood, it's red.'10 But what we learned from the body in communism is the very opposite: 'It is not red, it is blood': it is the indivisible postcommunist remainder that is not (yet?) re-integratable into the global immaterial and virtual world of new media.

\footnotetext{
${ }^{9}$ In the late 1980s and early 1990s, the Socialist Federal Republic of Yugoslavia (comprised of six republics: Bosnia and Herzegovina, Croatia, Macedonia, Montenegro, Serbia and Slovenia) experienced a period of intense political and economic crisis coinciding with the collapse of communism and resurgent nationalism in Eastern Europe. The first of the six countries to formally leave Yugoslavia, blaming Serbia of unjust domination of Yugoslavia's government, military and finances, was Slovenia in 1991; this triggered a ten-day war with the Yugoslav National Army. Croatia broke up at the same time as Slovenia, but the war lasted until 1995. In Bosnia and Herzegovina, the conflict turned into a bloodiest three-sided fight for territories (between Bosnian Muslims, Bosnian Serbs, and Bosnian Croats); it is estimated that more than 100,000 people were killed and two million people were forced to flee their homes. In Kosovo, violence flared in 1998 and lasted until 1999. Macedonia was the only country that enjoyed a peaceful separation in the fall of 1991, with sporadic armed conflicts later on in 2001 (ICTY, n.d.). On the Milošević's trial see Nevenka Tromp's book (2016).

${ }^{10}$ A French-Swiss film director, screenwriter and film critic was answering a question why there was so much blood in his movie Pierrot (Thomson, 2014: 412).
} 


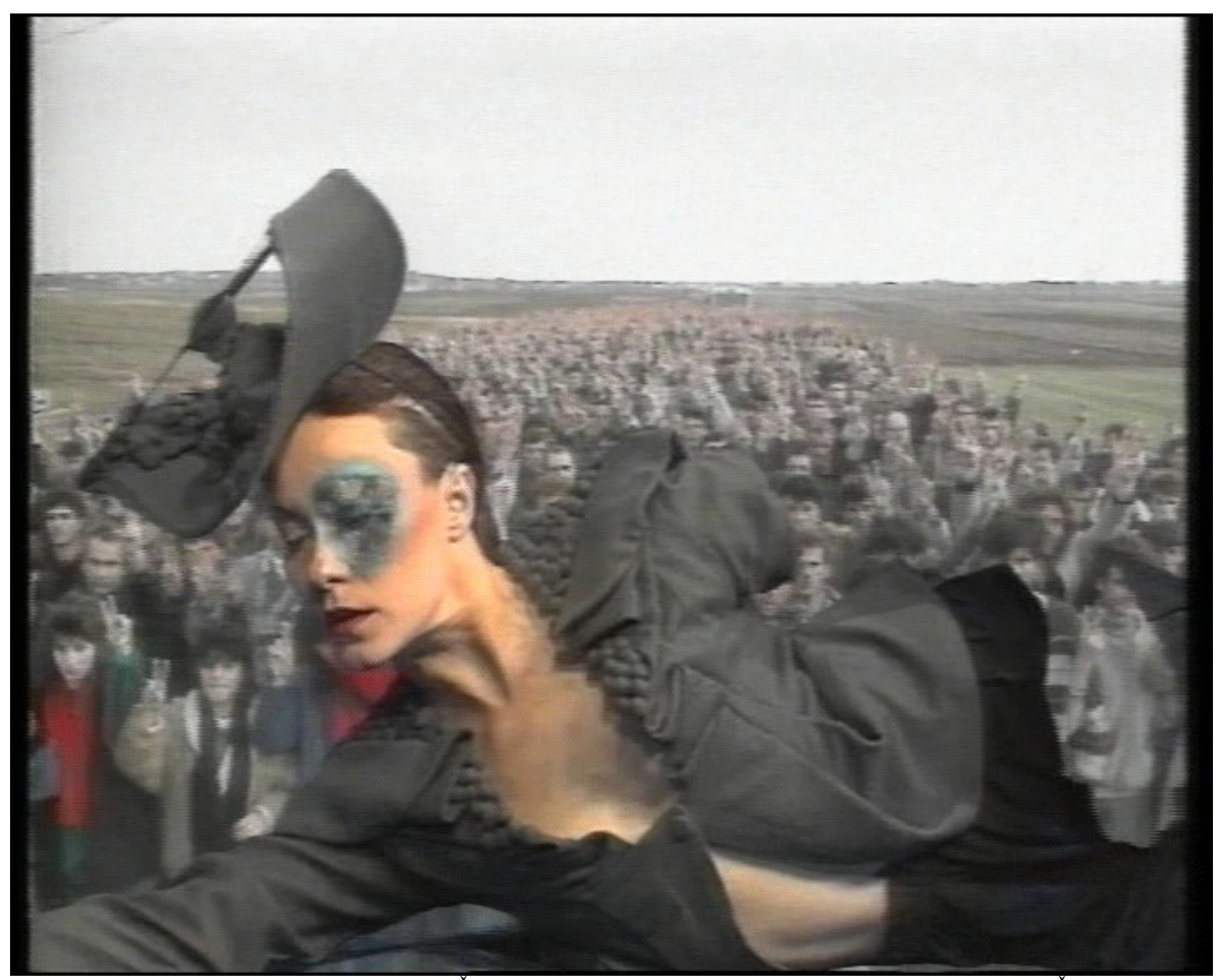

Figure 1. Marina Gržinić and Aina Šmid, Bilokacija (Bilocation), 1990. (C) Gržinić and Šmid.

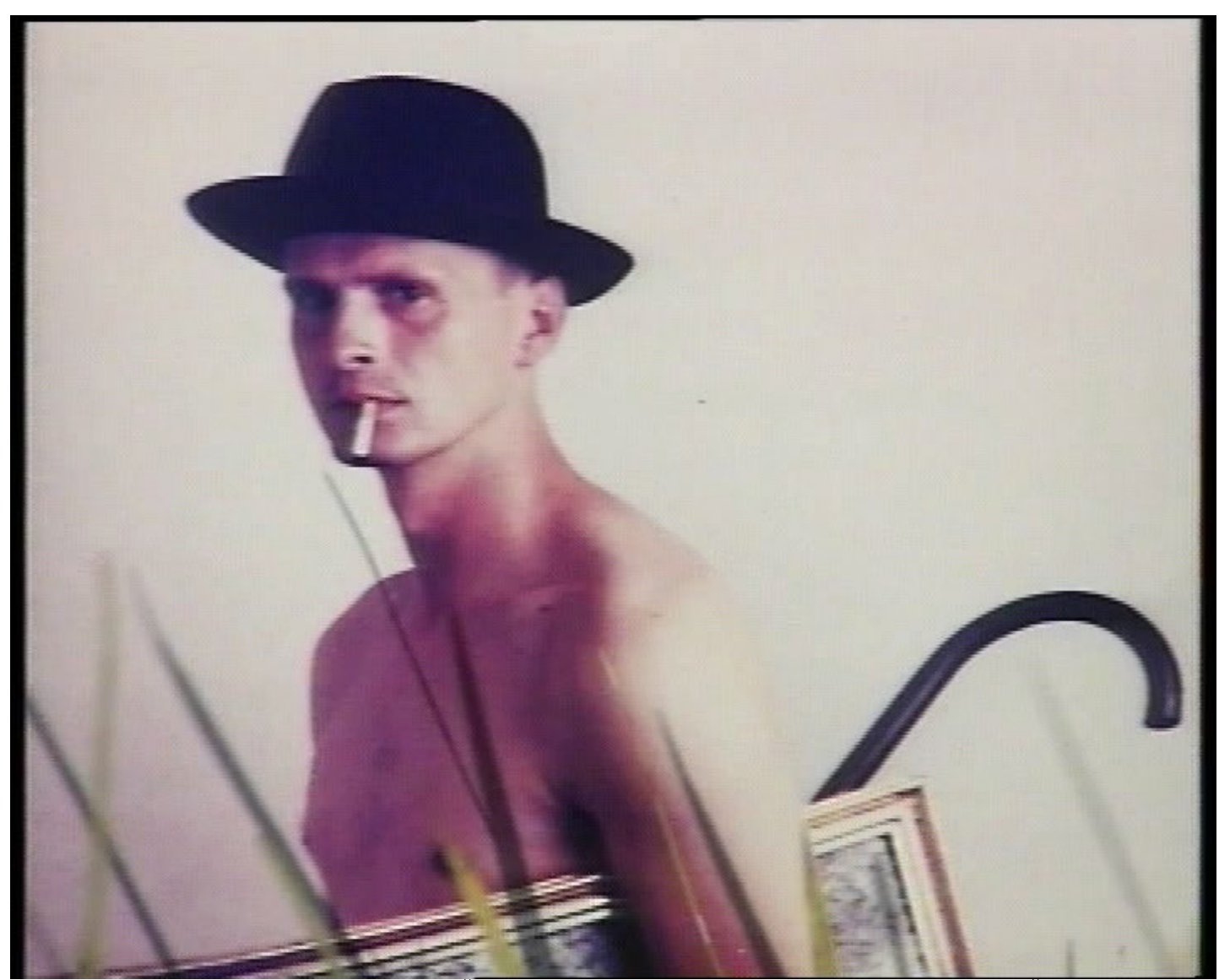

Figure 2. Marina Gržinić and Aina Šmid, Sejalec (The Sower), 1991. (C) Gržinić and Šmid. 


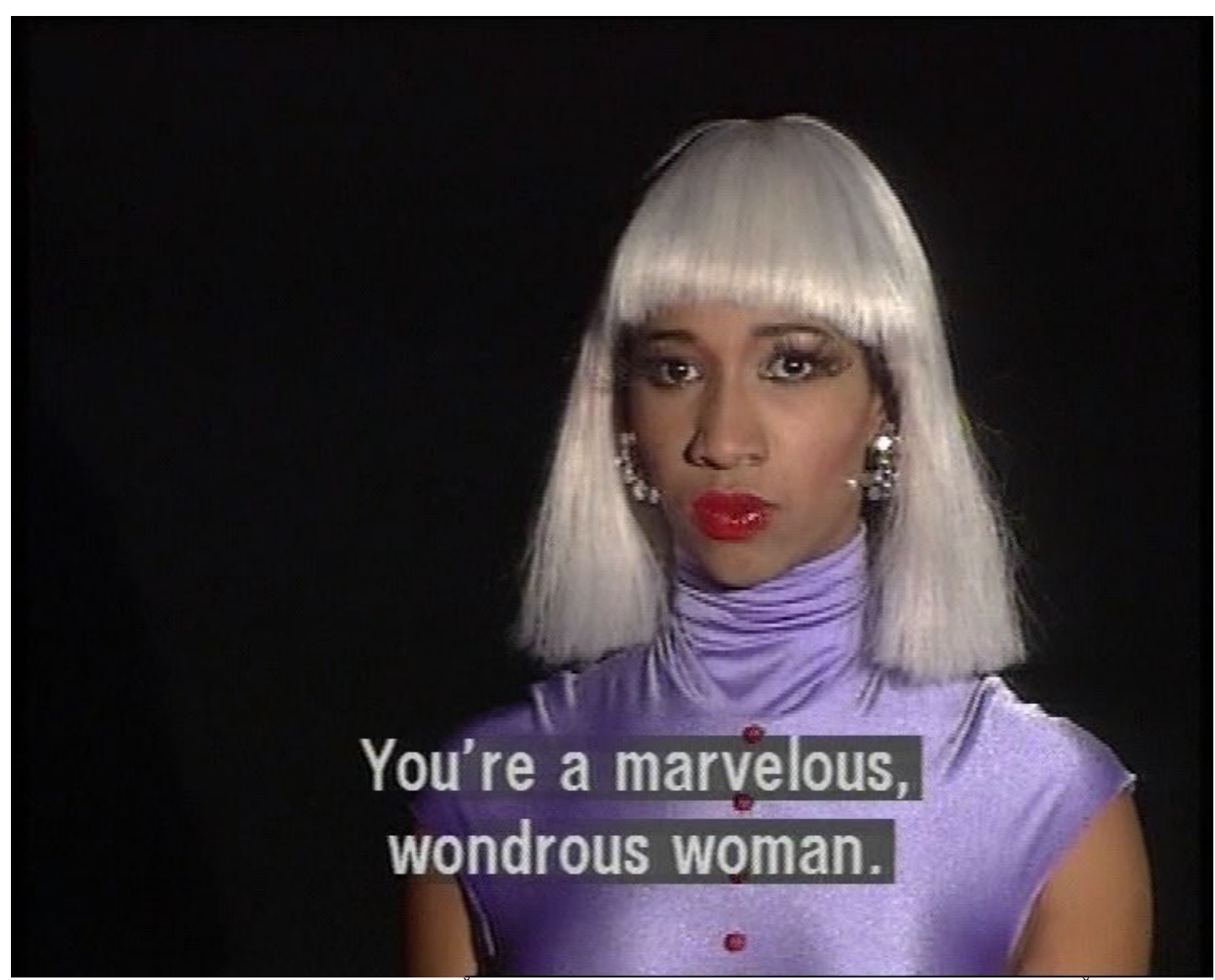

Figure 3. Marina Gržinić and Aina Šmid, Tri sestre (Three Sisters), 1992. (C) Gržinić and Šmid.

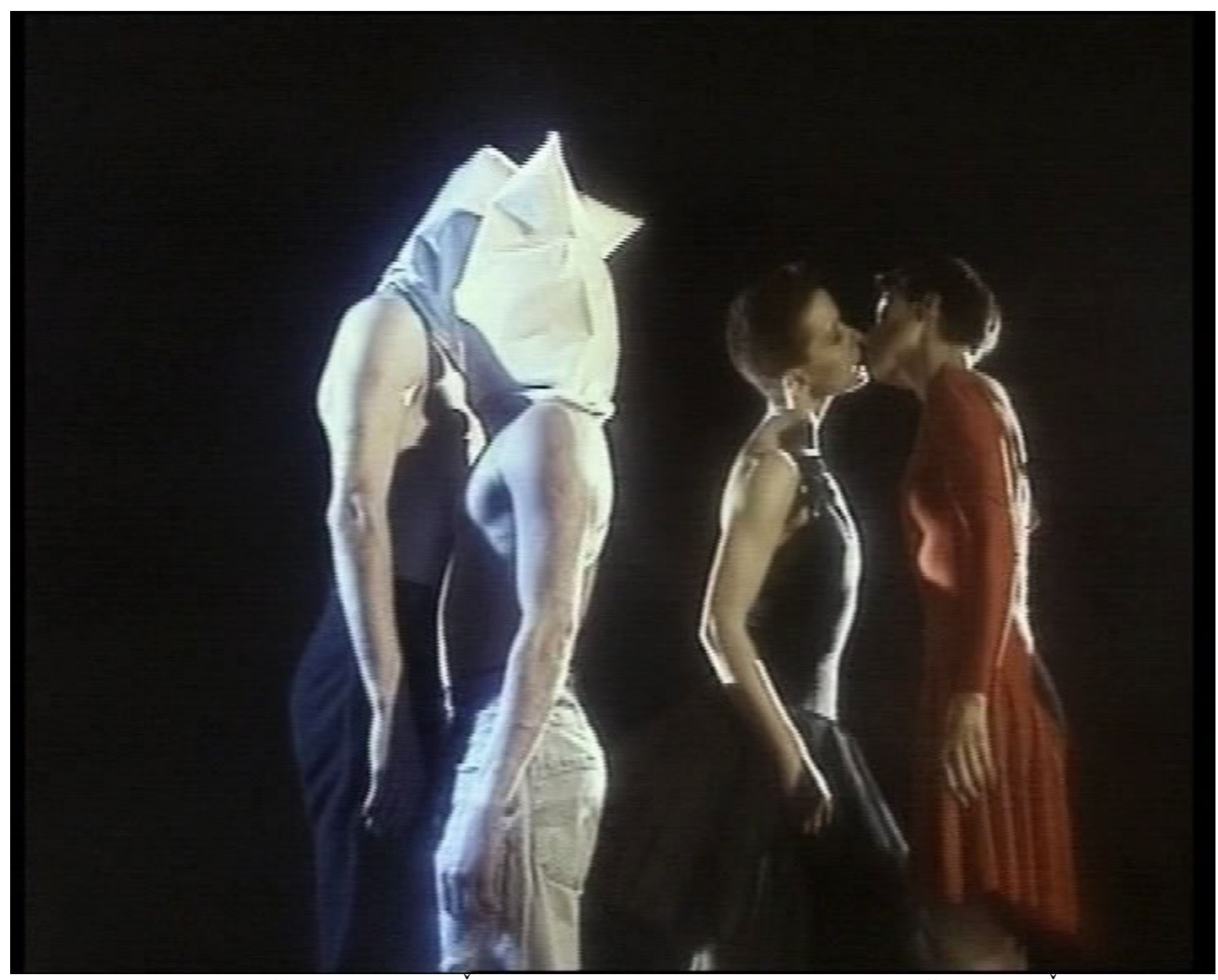

Figure 4. Marina Gržinić and Aina Šmid, Labirint (Labyrinth), 1993. (c) Gržinić and Šmid. 


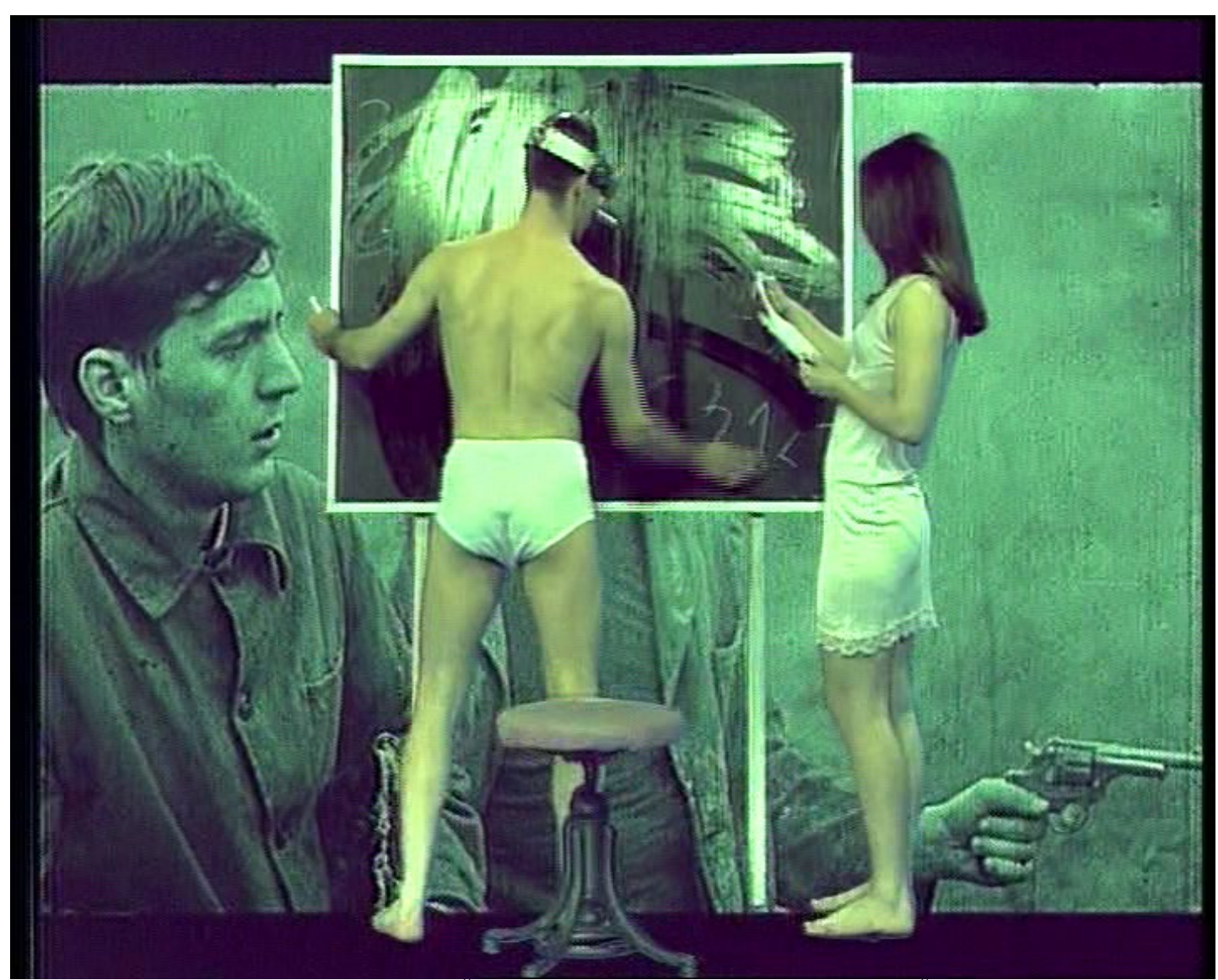

Figure 5. Marina Gržinić and Aina Šmid, Luna 10, 1994. C Gržinić and Šmid.

In the 1990s, this creative destiny was also shaped by a completely different political and artistic situation - in this period our videos were influenced, or more precisely, dominated, by the Balkan wars. We encrusted documentary footage of the violence with staged fictional material, and thus showed how electronic processes could be used to bring about the political organisation of the video image.

Since the end of the 1990s, we have been primarily interested in developing a critique of neoliberal 'turbocapitalism,' exploring processuality and performative politics, and undermining (and opposing) the notion of culture as merely a utopian site of (bourgeois) freedom and creativity. It is becoming, after all, increasingly obvious that today, thanks to neoliberal 'normalisation' processes, which ensure that citizens themselves contribute to and enforce their own self-censorship by internalising and normalising forms of control, culture has become, in its official institutions, production, and discourses, arguably the most repressive level of contemporary capitalist society and, indeed, since Slovenia is now a part of capitalism, of contemporary turbo-neoliberal Slovenian society.

The crisis of representation in contemporary art (and not only in video) is connected, therefore, with the extent to which we are able to relocate the conflict, the social contradiction, back in the work. Precisely because the politics of representation is still such an open question, we must ask: How can we make video art an explicitly political practice? In what way can this be done? Our answer comes in searching for ways to re/present conflict in the work of art, conflict that points to processes of social contradiction, racial injustice, and capital expropriation. This means reorganising the format of the video frame so it can be opened up to intervention, and re-appropriating the language of this intervention by linking it directly to art and culture as once again possible pertinent practices. But to do this, the medium and the knowledge it contains must be extended beyond the confines of Europe; our task, then, must be to examine Western democracy's relation to imperialism and colonialism, freedom and transfeminism.

Could you comment on queer politics in Slovenia and how you think it has changed over the years in relation to political changes in your country?

I will say that it is important to differentiate between a 'naive, benevolent' support of women's practices in Eastern Europe, on the one side, and the feminist and theoretical imperialism that can be unmistakably recognised throughout recent decades. As was exposed by bell hooks (1981), Gayatri Chakravorty Spivak (2008), Chandra Talpade Mohanty (1996), and Goldie Osuri (2009), for example, at the centre of such imperialism remains a colonial politics of representation, expressions of cultural tolerance and attempts to identify with the Other (wo/man). But this imperialism works hand in hand with the worship of capitalism as bringer of freedom, the 
celebration of a privatised selfhood, and a conservative, traditional gender politics that becomes a measure of biopolitical governmentality. It is important to understand that after the fall of the Berlin Wall, this Other was celebrated precisely by privileging identity politics and culture as divided from the social and political, not to mention the colonial and neoliberal.

Marie-Hélène Bourcier (2005) emphasises not only that queer feminism started to develop in its first wave by attacking heteronormativity, but that nowadays it is also important to engage in the questioning of homonormativity. Bourcier engages today with the critique of Butler and of the French materialist feminists and lesbians, notably Monique Wittig. ${ }^{11}$ What is central to the translation of the U.S. queer movement into European contexts are the questions posed by the Chicana, mestiza, and African American feminists and lesbian positions that imported ideas into early queer activisms in Europe. In the 1990s, Chicana and Asian feminists' positions asked for intersectionality. They also asked for their positions of empowerment to be recognised. Nonetheless, as pointed out by Bourcier concerning the European context: the political subject positions of identity politics were nullified by the structuralist and poststructuralist theories and their narratives concerning the death of the subject.

Bourcier stated very precisely that the bringing of the queer movement from the United States to Europe did not escape from provoking the same questions raised by the American queers of colour. Bourcier argues that in the USA context the queer of colour exposed how they were always suppressed by the white majority.

What was the result of the conceptual and political incompetence - let us ask following Bourcier - by many of the irresponsible and tainted white theoreticians of the West of Europe? The product of this process was inevitably racism and disregard for the positions of minorities. Bourcier argued that the choice was to either get rid of identity politics altogether or just to stop working in such a context due to its incapacity to recognise important points of difference within it. Bourcier explained when criticising the Republican Universalist claims that French intellectuals, followed by the official gay and lesbian movements have still not understood this argument and unfortunately continue to be missing the political potential of cultural identities.

To summarise, the possibility for a queer political materialism is to embrace the question of race that is according to Bourcier the 'Achilles heel' of white feminism since the first queer wave movement which occurred in Europe in the 1990s. To understand that the second wave queer started to bring forward this moment is very important. Moreover, queer theory of the first wave has constructed heterosexuality as its main enemy. Therefore, these questions are at the core of the transfeminist epistemological matrix. Latterly, Trans Studies has brought as a major contribution into the European context, foregrounding such topics such as labour, job insecurity, sex work, and I would say adding a very powerful questioning of the formation of the Western, occidental white epistemic matrix, which is actually a matrix of pure (colonial) violence.

Here a new demand for the critique of pseudo-naturality of the alignment of 'the same sex/same gender' type is also present (also called cis-gender). Indeed, this position has resulted in an enhancement of the gendered female subject who has been associated with a certain naturalisation of women (against the male subject, and of course many others, including transsexuals). It presupposes, as pointed out by Bourcier, the existence of a woman and of domination that erases all differences amongst and between women. This then results in declaring that sexist domination is equal to slavery but without questioning the colonial presuppositions that such a shift implies.

Regrettably, it resulted in a deletion of the issue of racism in western feminism, and with an absence of race/ethnicity in positions of feminist theory. Therefore, this is why the North American outsiders such as Audre Lorde $^{12}$ or the mestiza consciousness of Chicana lesbians such as Cherríe Moraga ${ }^{13}$ that live at the borders, are crucial for European feminists too, as they put into question this new purity of dogma. Donna Haraway's (1991) cyborg had initially the same aim. I am in sympathy with Bourcier who opposes any idea of female moral superiority, innocence, or arguments posing our greater closeness to nature.

The question remains whether European queer politics can be seen without a more precise re-elaboration of the relation between queer - and the other two constructed social categories of nationality, and race? And if we erase race from our critical framework of queer, our conceptualisation of queer (in the relation to nation-State and

\footnotetext{
11 Wittig was particularly interested in overcoming gender and the heterosexual contract. Her first novel was published in 1964 as L'Opoponax; her second, Les Guérillères, published in 1969, a collection of prose poems on lesbian love and the female body, is considered a landmark in lesbian feminism.

${ }^{12}$ American philosopher Audre Lorde (1934-1992) described herself as a 'black, lesbian, mother, warrior, poet.' She was a noted prose writer as well as poet, dedicated to confronting and addressing injustices of racism, sexism, classism, and homophobia. She is the author of The First Cities (1968), Cables to Rage (1970), From a Land Where Other People Live (1972), New York Head Shop and Museum (1974), Coal (1976), The Black Unicorn (1978), The Cancer Journals (1980), Zami: A New Spelling of My Name (1982), Sister Outsider: Essays and Speeches (1984), A Burst of Light (1988) (see Poetry Foundation, n.d.).

${ }^{13}$ Cherrie Moraga is a Chicana writer, poet, essayist, playwright and feminist activist. She began as a co-editor (with Gloria Anzaldúa) of the avant-garde feminist anthology This Bridge Called My Back: Writings by radical women of color (1981). Her latest books include: Waiting in the Wings: Portrait of a queer motherhood (1997), A Xicana Codex of Changing Consciousness: Writings, $2000-$ 2010 (2011), and Native Country of the Heart: A memoir (2019) (see https://cherriemoraga.com).
} 
its processes of racialisations) - wouldn't our institutionalised, structural and social racism(s) end up naturalising what as feminist thinkers and activists we would wish to denaturalise?

\section{REFERENCES}

Bourcier, M.-H. (2005). Sexpolitiques: Queer zones 2. Paris: La Fabrique.

Corsani, A. (2007). Beyond the myth of woman: The becoming-transfeminist of (post)Marxism. Substance, 36(1), 107-38.

Documenta (n.d.). Documenta X. Available at: https://www.documenta.de/en/retrospective/documenta_x.

Fanon, F. (1967). Black Skin, White Masks. Translated by Charles Lam Markmann. New York: Grove.

Foucault, M. (2010). The Birth of Biopolitics: Lectures at the College de France 1978-1979. Edited by Michel Senellart. Translated by Graham Burchell. New York: Picador.

Grosfoguel, R. (2007). The epistemic decolonial turn: Beyond political-economy paradigms. Cultural Studies, 21(23), 211-223. https:// doi.org/10.1080/09502380601162514

Gržinić, M. (Ed.) (2018). Border Thinking: Disassembling histories of racialized violence. Berlin: Sternberg Press.

Gržinić, M., and Eisenstein, A. (eds) (1999). The Spectralization of Technology: From elsewhere to cyberfeminism and back. Institutional Modes of the Cyberworld. Maribor: MKC.

Gržinić, M., and Reitsamer, R. (eds) (2008). New Feminism: Worlds of Feminism, queer and networking conditions. Vienna: Locker.

Gržinić, M., and Tatlić, Š. (2014). Necropolitics, Racialization, and Global Capitalism: Historicization of biopolitics and forensics of politics, art, and life. Lanham: Lexington Books.

Haraway, D. (1991). Simians, Cyborgs, and Women: The reinvention of nature. London: Free Association Books.

Hook, D. (2011). Retrieving Biko: A black consciousness critique of whiteness. African Identities, 9(1), 19-32.

hooks, b. (1981). Ain't I a Woman?: Black women and feminism. Boston: South End Press.

ICTY (International Criminal Tribunal of Yugoslavia) (n.d.). The conflicts. Available at: https://www.icty.org/en/about/what-former-yugoslavia/conflicts. (Accessed 9 May, 2020).

Johnston-Arthur, A. E., and Kazeem B. (2007). CAFE DEKOLONIAL. 'SAG ZUR MEHLSPEIS'LEISE SERVUS...' [Decolonial café: 'Say silently Good Bye to the pastry']. Reartikulacija, (1), 8-9. Available at: http://grzinic-smid.si/wp-content/uploads/2013/02/Rear2007tikulacija1SLO.pdf.

Kancler, T. (2013). Tongue untied, tongue with tongue. Mining the binary matrix. Identities: Journal for Politics, Gender and Culture, 10(1-2), 14-19.

Mbembe, A. (2003). Necropolitics. Translated by Libby Meintjes. Public Culture, 15(1), 11-40. https://muse.jhu.edu/article/39984.

Mitropoulos, A. (2009). Legal, tender. Reartikulacija, (7), 5-6. Available at: http://grzinic-smid.si/wpcontent/uploads/2013/02/Rear2009tikulacija7.pdf.

Osuri, G. (2009). Identity and complicity in necropolitical engagements: The case of Iraq. Reartikulacija, (8), 10-12. Available at: http:/ / grzinic-smid.si/wp-content/uploads/2013/02/Rear2009tikulacija8.pdf.

PISG (Legal Information System) (n.d.). Family Code (DZ) ‡. Available at: http:/ / www.pisrs.si/Pis.web/pregledPredpisa?id=ZAKO7556\# . (Accessed 17 May, 2020).

Poetry Foundation. (n.d.). Audre Lorde. Available at: https://www.poetryfoundation.org/poets/audre-lorde. (Accessed 9 May, 2020).

Preciado, P. B. (2013[2008]). Testo Junkie: Sex, drugs, and biopolitics in the pharmacopornographic era. Translated by Bruce Benderson. New York: The Feminist Press.

Recalcati, M. (2019). Le nuove melanconie: Destini del desiderio nel tempo ipermoderno [The new melancholies: Fates of desire in hypermodern time]. Milano: Raffaello Cortina Editore.

Reitsamer, R. (2005). In the mix: Race, whiteness and gender in popular culture. Lecture presented at the 2005 City of Women festival, 13 October 2005, Klub Monokel, AKC Metelkova City, Ljubljana, Slovenia. Abstract available at: http://www.cityofwomen.org/en/content/2005/project/mix-race-whiteness-and-genderpopular-culture. (Accessed 17 May, 2020).

Spivak, G. C. (2008). Can the Subaltern Speak? Postkolonialität und subalterne Artikulation [Can the subaltern speak? Postcoloniality and subaltern articulation]. Translated by Alexander Joskowicz and Stefan Nowotny. Vienna: Verlag Turia+Kant.

Talpade Mohanty, C., and Alexander, M. J. (eds) (1996). Feminist Genealogies, Colonial Legacies, Democratic Futures. New York: Routledge Press.

Thomson, D. (2014). The New Biographical Dictionary of Film: Sixth edition. New York: Knopf Doubleday Publishing Group. 
Tromp, N. (2016). Prosecuting Slobodan Miloševic: The unfinished trial. New York: Routledge.

Vishmidt, M. (n.d.). In conversation with the Factory of Found Clothes. Available at: http://www.boehmkobayashi.de/tradecenter/ArchivNatalia.html. (Accessed 9 May, 2020).

\section{WEBSITES}

https://www.obn.org

https://radiostudent.si

http://www.magnus.si/en/

https://www.skuc.org

http://www.cityofwomen.org/en

https://cherriemoraga.com

Citation: Munt, S. R. (2020). Interview with Marina Gržinić. Feminist Encounters: A Journal of Critical Studies in Culture and Politics, 4(2), 31. https://doi.org/10.20897/femenc/8519

Copyright (C) 2020 by Author/s and Licensed by Lectito BV, Netherlands. This is an open access article distributed under the Creative Commons Attribution License which permits unrestricted use, distribution, and reproduction in any medium, provided the original work is properly cited. 